\title{
Anti - diabetic and anti-obesity effects of plant extract from Cleome droserifolia (SAMWA)
}

\author{
*Eman G. E. Helal, **Hafiza A. Sharaf and ***Fathy E. Mattar \\ * Zoology Department Faculty of science for girls, Al-Azhar University, **Pathology \\ Department, National Research Center, and ***Faculty of Medicine, Al-Azhar \\ University Egypt
}

\begin{abstract}
In this work the mechanism of the hypoglycemic effect of an aqueous extract from Cleome droserifolia (SAMWA) was studied in a group of glucose intolerant senile rats and compared with normal senile control rats. The plant extract significantly suppressed the rise in blood glucose concentration. The hypoglycemic effect of the plant extract without increasing insulin secretion was explained by: 1) potentiation of peripheral and hepatic insulin sensitivity, 2) by diminishing intestinal glucose absorption, which was evident by blunting plasma glucose levels throughout the oral glucose challenge. This was accompanied by a significant decrease of liver glycogen content and a highly significant increase in leptin concentration which may suggest an anti-obesity role for the plant extracts. Plant extracts also decreased serum urea nitrogen. No changes on liver or heart function were observed. In histological sections of liver and kidney minor changes were noticed. These extracts might prove to have a promising therapeutic value in the treatment of diabetes mellitus. Besides its suppression to hepatic glucose output, SAMWA beneficial therapeutic finding in favor of the plant as a replacement for insulin which is the most important drug that brings bout this effect.
\end{abstract}

\section{Introduction}

Although diabetes mellitus is a multifunctional disease with several causes and with complex consequences any consideration of the disease must deal with the importance of B- cell function and the production of adequate amount of active insulin.

Insulin secretion is primarily stimulated by glucose and a variety of non-glucose secretogogues including arginine, isoporoterenal, glucagon and secretin. However, studies in vitro( Levin et al.,1972 and Gerich at al., 1974) and in vivo (Efendic et al., 1971) confirmed that the amount of insulin secreted in response to these non. glucose stimuli depends basically on the underlying glucose concentration.

In the non-insulin dependent diabetes mellitus (NIDDM), the total B-

cell mass has been reported as normal (Rahier et al., 1983), or only partially reduced (Gepts, 1972) and the pancreatic insulin reserve appears, in itself, sufficient for a normal glucose homeostasis. In NIDDM, a defect seems located in the insulin secretary capability of the pancreatic B-cell but it is unknown whether this deficiency is of a primary or secondary origin (Reaven,1984).

Secretion appears to result from an autoimmune process involving the pan creatic insulin producing cells leading to their destruction with development of diabetic syndrome (O'Brien et al., 1996) The autoimmune process is prob ably triggered by some environmental factors (viral or toxic) in genetically susceptible individuals (Grunfield et al., 
1995; Yoon, 1990). Thus, these factors appear to interact to produce insulin deficiency, genetic factors, immunolo gical factors and environment fact ors.(Yoon, 1990).

Non insulin dependent diabetes mellitus (NIDD) is usually associated with old age (Baird,1984). Senile rats are considered a good model for NIDD since they normally show high blood glucose level and glucose intolerance (Mattar and Moustafa, 1994; Moustafa et al., 1995). In this type of diabetes, the total p-cell mass has been reported as normally (Rahier et al.,1983) or only partially reduced(Gepts,1972) and the pancreatic insulin reserve appears, in itself, sufficient for a normal glucose homeostasis. In this case, any condit ioning effect of a drug or herb can be attributed to activation of insulin receptors and/ or post glucose transport metabolic activity (Mattar and Moustafa, 1994; Moustafa et al., 1995) The history of spices and herbs was closely related to the old civilization in Egypt, India, Irak, Iran and China. The ancient Egyptians used plants in some medical treatments.

Plants were widely used in folk remedy such as sage which was used as stimulant, astringent, antifungal tonic and carminative where as peppermint was used as tonic, stomachic and as an insectifuge (Crisan and Hodis, 1972; Roberto, 1984). Thyme was used as antiseptic, antispasmodic, antibacterial and for relieve of pain in head (Farrage et al., 1986; Kaur S. and Shinna, 1982). Funnel can be employed as substitute for cod-liver oil in scrofula, rickets and anemia and the oil of dill was used in the flatulence of infants and was useful as a vehicle for children's medicine generally (Grieve, 1959).Cleome drose rifolia is used as a decoction in Sinai by Bedouins and other inhabitants of the area for the treatment of diabetes mellitus.

(El-Seifi et al ., 1993) provided the evidence which substantiated the traditional claim for oral hypoglycemic effect of cidroserifolia in diabetic rats.

The present study was planned to achieve the following goals. The first was to study the effect of both water and ethanolic extracts on the senile rats with glucose intolerance. The second was to follow up its effect on some vital organs as liver and kidney. The last was to elucidate its mode of action and which extract is more effective.

\section{Material And Methods}

Animals:

Male adult (3-4 month) and senile (15-18 month) albino rats (Sprague Dawley strain) were used in this study. Their body weight ranged from 120-150 gm for adult and 250-300gm for senile. They were acclimatized in the laboratory for one week.

\section{Glucose tolerance:}

Rats were fasted overnight (10$12 \mathrm{hr}$ ) and then drenched glucose solution $(3 \mathrm{~g} / \mathrm{kg}$.b.w) by gastric intuba tion. Blood was collected from the caudal vein by cutting the tip of tail. Glucose level was then measured for both adult and senile rats over 3 hour period. Senile rats with serum glucose level ranging from $180-300 \mathrm{mg} \%$ were considered as intolerant in the experiment.

\section{Preparation of plant extract:}

Cleome droserifolia (SAMWA) was obtained from a local market. The infusions(aqueous and ethnolic extracts) were prepared by using Sockslet apparatus.

\section{Experimental design:}

Five young male albino rats and fifteen senile diabetic ones were allotted among four groups each of 5 rats. Two groups served as control (one young and 
one senile diabetic group). Every animal in the other two groups of 5 senile rats each was drenched $6 \mathrm{mg} / \mathrm{kgm} /$ day of aqueous or ethanolic extracts of SAMWA for 30 days.

\section{Blood sampling}

Blood samples were collected at the end of the experiment from the orbital plexus by means of heparinized capillary glass tubes according to the method of Schermer(1967). Blood was collected, either on EDTA for hematological studies, or in glass centrifuge tubes to separate the serum. After 10 minutes of centrifugation of the blood at $5000 \mathrm{rpm}$, supernatant sera were immediately separated for biochemical analysis.

\section{Hematological study}

Hemoglobin concentration was determined according to Van-kampen \& Zalstra(1961).

Red and white blood cell count and hematocrit values (Hct) were estimated using the technique of Rodak(1995).

\section{Biochemical study:}

The biochemical analysis was carried out on the blood sera. Glucose determination was based on the enzymatic method described by Siest \&Schief(1981). Liver glycogen content was determined according to the technique described by Cara et al. (1956). Serum insulin and testosterone concentrations were measured by direct immuoenzymatic determination descry bed by Maruyama, (1987). Serum gluc agon and leptin concentrations were measured by radioimmuoassay techn iques described by Heding, 1971 and Zhongmin et al., 1996 respectively. Serum Aspartate amine transferase (AST) and alanine amino transferase (ALT) activities were accomplished using the method of Reitman and Frankel(1975). $\gamma$-glutamyltranspeptidase was estimated by the method of Meister et al.(1981). Alkaline phosphatase (AP) and lactic dehydrogenase (LDH) activi ties were determined according to Belifield and Goldberg (1971) and Raabo (1963) respectively and the activity of Creatine Kinase (CK) Was determined according to the method described by Rosalki(1967) using Pointe Scientific, Inc kits, USA. Activity of acid phosphatase was determined by the method of King and Armstrong (1934). Total proteins were estimated using the Biuret method as described Doumas (1975). Albumin was determined according to the method of Webester, (1977) and urea nitrogen was determined using the method of Knight et al (1972), while serum cholesterol was determined as reported by Fossati and Medici (1987) and triglycerides were determined by the method of Rojkin et al.(1974).

\section{Histological Study:}

At the end of the experimental period, animals were dissected and liver and kidneys were excised immediately. Small pieces were fixed in neutral formol for 48 hours, dehydrated, cleared and embedded in paraffin wax. Thin $6 \mu \mathrm{m}$ sections were cut, mounted on clean slides and stained by hematoxylin and eosin(Drury and Wallington, 1980). The specimens were microscopically examined and nuclear diameter was measured by computerized image analyzer.

\section{Statistical manipulation:}

Student, t-test was the statistical analysis used to compare between the means obtained for the different parameters obtained from the different experimental animal groups. Significant differences between the means of control and treated groups were consid ered only at $\mathrm{p} \leq 0.05$ (Sokal \& Rahif, 1981). Statistical analysis and graphic illustration was performed using MS Excell XP software. 


\section{Results}

\section{Glucose tolerence}

The data of the present study showed significant high value in the level of fasting serum glucose of senile rats when compared to that of adults.
Senile rats showed glucose intolerance or even frank diabetes mellitus when compared with adults (Table 1, figure 1), so they were a good model to the present study.

Table 1: mean \pm standard error of blood glucose level $(\mathrm{g} / \mathrm{dl})$ at different periods after drenching $3 \mathrm{~g} / \mathrm{kg}$ body weight of glucose to adult and senile animals.

\begin{tabular}{|l|l|l|l|l|l|l|l|}
\hline time(min.) & & fasting & 30 & 60 & 90 & 120 & 150 \\
\hline \multirow{2}{*}{ young } & Mean & 84 & 130.6 & 172.6 & 160 & 130 & 94.6 \\
\cline { 2 - 8 } & S.E. & 3.4 & 4.4 & 3.8 & 4.8 & 7 & 4.2 \\
\hline \multirow{2}{*}{ Senile } & Mean & 230 & 260 & 312 & 331 & 309 & 257 \\
\cline { 2 - 8 } & S.E. & 15.5 & 14.2 & 16.8 & 23.15 & 25.3 & 21.7 \\
\hline
\end{tabular}

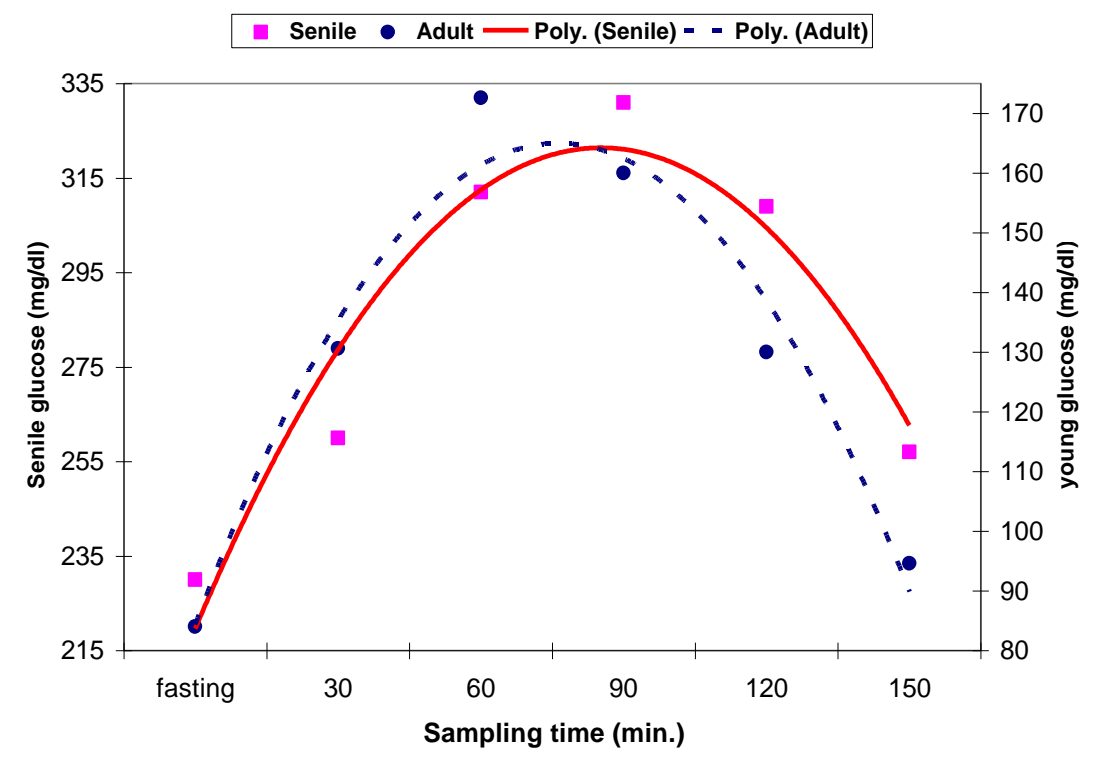

Figure 1: Glucose tolerance curve for young and senile animals.

\section{Hematological parameters}

The data of the hematological parameters of senile rats treated with water or ethanol extracts of SAMWA are shown in table (2), figures $(2,3)$. Generally, red blood cell (RBC) counts were significantly decreased in animals treated with either water or ethanolic extract through the treatment period.
Relevant to the decrement in $\mathrm{RBC}$ count, $\mathrm{Hb} \%$, Hct\%, MCV were significantly reduced in association with both extract treatments.

On the other hand, no significant change was recorded in WBC count, $\mathrm{MCH}$ or $\mathrm{MCHC}$ (table 2). 
Table (2) some haemtological parameters in senile control and senile rats treated with water or ethonolic extract of Cleome dreserifolia .

\begin{tabular}{|c|c|c|c|c|c|c|c|c|c|}
\hline 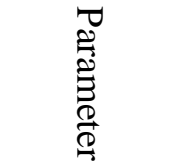 & & control & $\begin{array}{l}\text { water } \\
\text { extract }\end{array}$ & $\begin{array}{l}\text { Ethanol. } \\
\text { extract }\end{array}$ & 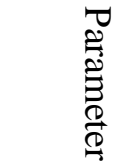 & & control & $\begin{array}{l}\text { water } \\
\text { extract }\end{array}$ & $\begin{array}{l}\text { Ethanol. } \\
\text { extract }\end{array}$ \\
\hline$\underset{6}{\mathrm{RBC}} \times 10$ & $\begin{array}{l}- \\
X \\
\text { S.E } \\
P \\
\end{array}$ & $\begin{array}{l}5.94 \\
.14\end{array}$ & $\begin{array}{l}4.3 \\
.08 \\
\leq 0.01\end{array}$ & $\begin{array}{l}4.78 \\
.216 \\
\leq 0.01\end{array}$ & $\begin{array}{l}\text { MCV } \\
\text { D1 }\end{array}$ & $\begin{array}{l}- \\
X \\
\text { S.E } \\
\text { P }\end{array}$ & $\begin{array}{l}74.48 \\
1.08\end{array}$ & $\begin{array}{l}94.5 \\
1.45 \\
\leq 0.01\end{array}$ & $\begin{array}{l}88.42 \\
.57 \\
\leq 0.01\end{array}$ \\
\hline $\begin{array}{l}\text { WBC } \\
X 10^{3}\end{array}$ & $\begin{array}{l}- \\
X \\
\text { S.E } \\
P\end{array}$ & $\begin{array}{l}8.3 \\
.3\end{array}$ & $\begin{array}{l}9.1 \\
.16\end{array}$ & $\begin{array}{l}8.8 \\
.26\end{array}$ & $\begin{array}{l}\mathrm{MCH} \\
\mathrm{Pg}\end{array}$ & $\begin{array}{l}- \\
X \\
\text { S.E } \\
P\end{array}$ & $\begin{array}{l}24.6 \\
.9\end{array}$ & $\begin{array}{l}27.34 \\
.52\end{array}$ & $\begin{array}{l}27.8 \\
.89\end{array}$ \\
\hline $\begin{array}{l}\mathrm{HB} \\
8 \%\end{array}$ & $\begin{array}{l}- \\
X \\
\text { S.E } \\
P\end{array}$ & $\begin{array}{l}14.6 \\
.29\end{array}$ & $\begin{array}{l}13.04 \\
.17 \\
\leq 0.01\end{array}$ & $\begin{array}{l}13.16 \\
.19 \\
\leq 0.01\end{array}$ & $\begin{array}{l}\mathrm{MCHC} \\
\%\end{array}$ & $\begin{array}{l}- \\
X \\
\text { S.E } \\
P\end{array}$ & $\begin{array}{l}33.48 \\
.87\end{array}$ & $\begin{array}{l}32.1 \\
.63\end{array}$ & $\begin{array}{l}31.32 \\
.3\end{array}$ \\
\hline $\begin{array}{l}\mathrm{HCT} \\
\%\end{array}$ & $\begin{array}{l}- \\
X \\
\text { S.E } \\
\text { P } \\
\end{array}$ & $\begin{array}{l}43.6 \\
.54\end{array}$ & $\begin{array}{l}40.6 \\
.46 \\
\leq 0.05\end{array}$ & $\begin{array}{l}40 \\
.43 \\
\leq 0.05\end{array}$ & & & & & \\
\hline
\end{tabular}

$\square$ control $\square$ water extrac $\square$ e thanol extrac

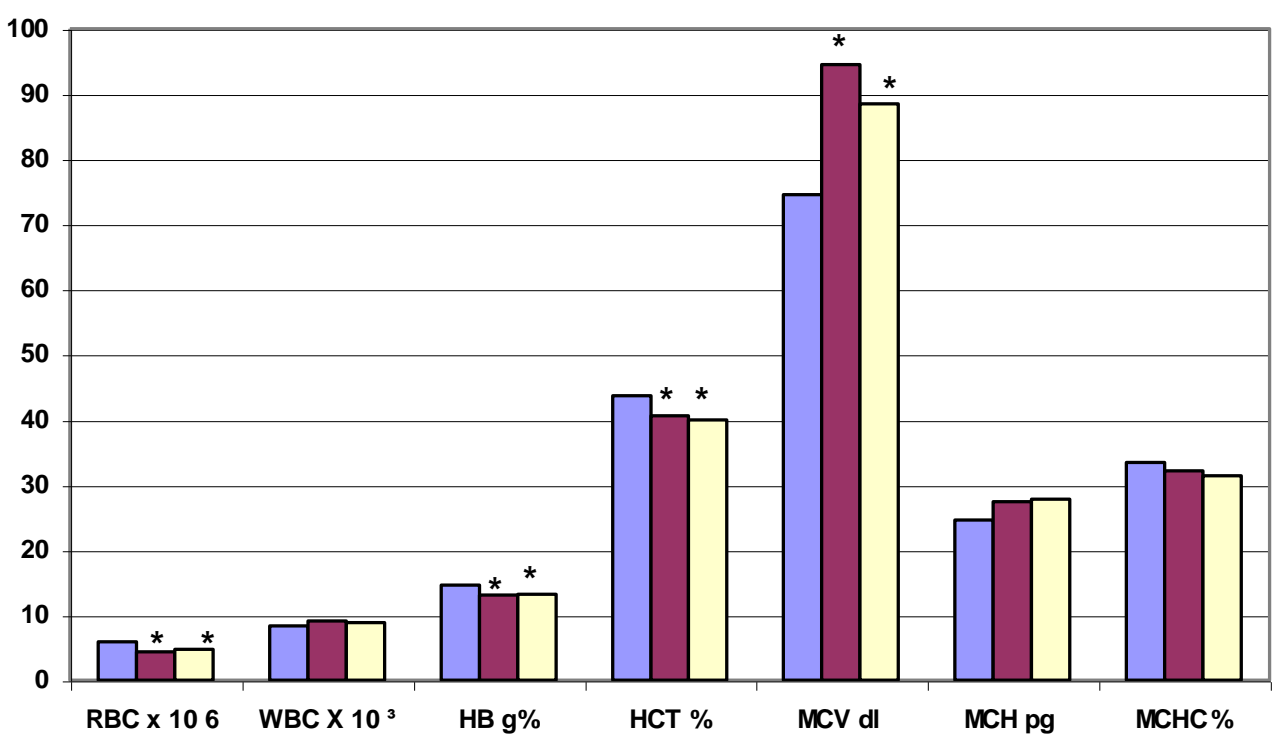

Figure (2) Some haemtological parameters in senile control and senile rats treated with water or ethonolic extract of Cleome dreserifolia. Asterisks indicate significant difference from control. 
Table (3) Serum glucose, hormonal activity and liver glycogen

\begin{tabular}{|c|c|c|c|c|c|c|c|c|c|}
\hline 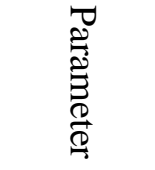 & & control & $\begin{array}{l}\text { water } \\
\text { extract }\end{array}$ & $\begin{array}{l}\text { Ethanol. } \\
\text { extract }\end{array}$ & 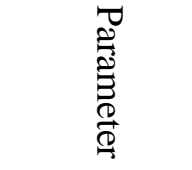 & & control & $\begin{array}{l}\text { water } \\
\text { extract }\end{array}$ & $\begin{array}{l}\text { Ethanol. } \\
\text { extract }\end{array}$ \\
\hline $\begin{array}{l}\text { Glucose } \\
\mathrm{mg} \%\end{array}$ & $\begin{array}{l}- \\
X \\
\text { S.E } \\
P \\
\end{array}$ & $\begin{array}{l}225.2 \\
.15\end{array}$ & $\begin{array}{l}103^{*} \\
6.25 \\
\leq 0.01\end{array}$ & $\begin{array}{l}100^{*} \\
6.7 \\
\leq 0.01\end{array}$ & $\begin{array}{l}\text { Glucagon } \\
\text { (pg/ml) }\end{array}$ & $\begin{array}{l}- \\
X \\
\text { S.E } \\
P \\
\end{array}$ & $\begin{array}{l}268 \\
7.69\end{array}$ & $\begin{array}{l}219 \\
1.67\end{array}$ & $\begin{array}{l}220.6 \\
6.92\end{array}$ \\
\hline $\begin{array}{l}\text { Liver } \\
\text { glycogen } \\
\mathrm{mg} / \mathrm{g} \\
\text { tissue } \\
\end{array}$ & $\begin{array}{l}- \\
\\
\text { S.E } \\
P \\
\end{array}$ & $\begin{array}{l}8.42 \\
.24\end{array}$ & $\begin{array}{l}10.08^{*} \\
.84 \\
\leq 0.01 \\
\end{array}$ & $\begin{array}{l}10.18^{*} \\
.63 \\
\leq 0.01 \\
\end{array}$ & $\begin{array}{l}\text { Leptin } \\
\text { (mg/dl) }\end{array}$ & $\begin{array}{l}- \\
\\
\text { S.E } \\
P \\
\end{array}$ & $\begin{array}{l}330 \\
0.18\end{array}$ & $\begin{array}{l}420^{*} \\
0.26 \\
\leq 0.05 \\
\end{array}$ & $\begin{array}{l}420 \quad * \\
0.26 \\
\leq 0.05\end{array}$ \\
\hline $\begin{array}{l}\text { Insulin } \\
\mu \mathrm{U} / \mathrm{ml}\end{array}$ & $\begin{array}{l}- \\
X \\
\text { S.E } \\
\text { P }\end{array}$ & $\begin{array}{l}58.4 \\
2.37\end{array}$ & $\begin{array}{l}68.8 \\
.17\end{array}$ & $\begin{array}{l}68.8 \\
.33\end{array}$ & $\begin{array}{l}\text { Testesteron } \\
(\mu \mathrm{g} / \mathrm{ml})\end{array}$ & $\begin{array}{l}- \\
X \\
\text { S.E } \\
P\end{array}$ & $\begin{array}{l}470 \\
.038\end{array}$ & $\begin{array}{l}520 \\
.027\end{array}$ & $496 \quad 0.05$ \\
\hline
\end{tabular}

\section{Biochemical parameters}

The biochemical parameters are represented in tables $(3,4)$ and figure $(4,5,6)$. There was a statistically significant reduction in serum glucose level and significant increase in liver glycogen content as compared to control. There was an increase in the level of insulin and a decrease in the level of glucagons but the changes were not statistically significant. The level of leptin was significantly higher than control, but the increase in the level of testosterone was not statistically significant.

$\square$ Control $\square$ W ater extract $\square$ ethanol extract

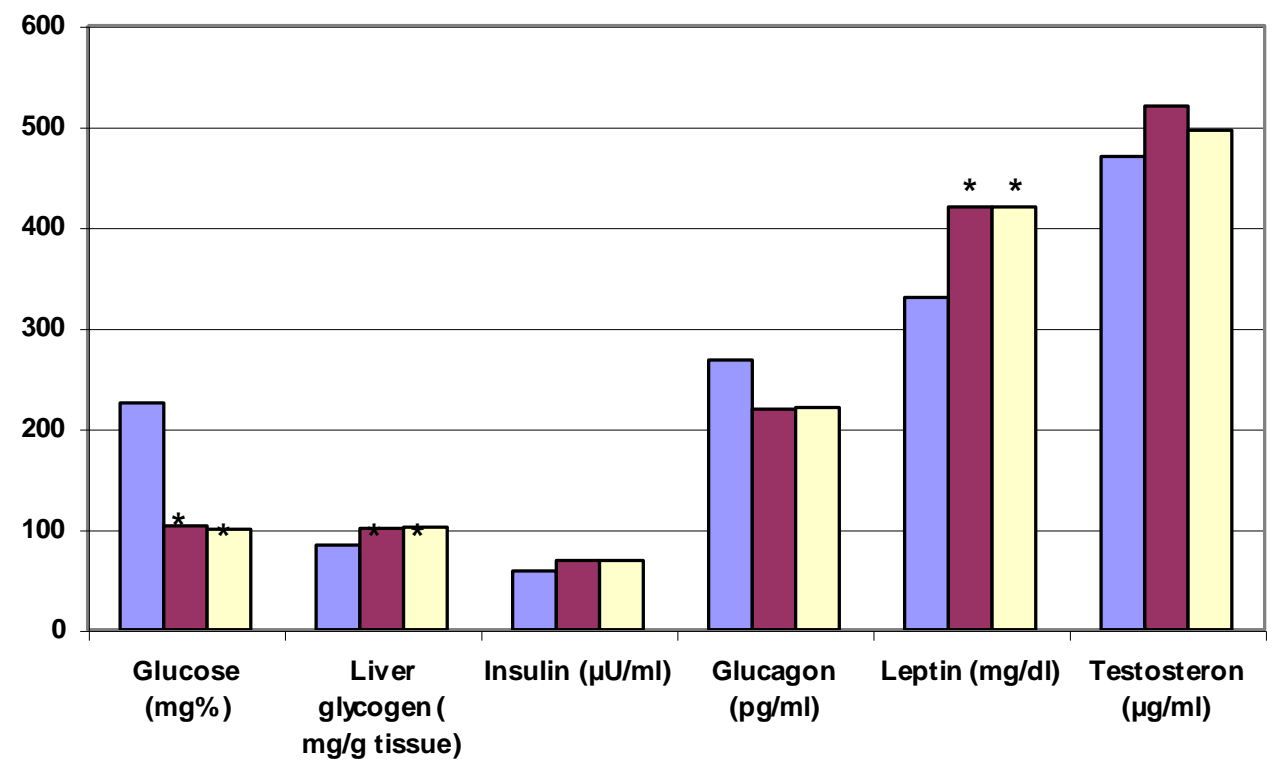

Figure (3) Serum glucose, hormonal activity, and liver glycogen levels. The asterisk represents a statistically significant difference between treated and control $(p \leq 0.05)$ 
The activity of the enzymes reflecting liver and kidney function (figure 4) was not significantly different from control. The level of total lipids (figure 5) was significantly lower than control. However, the change in the level of cholesterol, and triglycerides was not statistically significant. The level of total protein, albumin and globulin (figure 6) was also not significant. However, urea nitrogen was significantly lower than control.

Table (4): Liver function, kidney function, protein and lipid profile

\begin{tabular}{|c|c|c|c|c|c|c|c|c|c|}
\hline Parameter & & control & $\begin{array}{l}\text { water } \\
\text { extract }\end{array}$ & $\begin{array}{c}\text { Ethanol. } \\
\text { extract }\end{array}$ & Parameter & & control & $\begin{array}{l}\text { water } \\
\text { extract }\end{array}$ & $\begin{array}{c}\text { Ethanol. } \\
\text { extract }\end{array}$ \\
\hline $\begin{array}{l}\mathrm{AST} \\
\mathrm{U} / \mathrm{ml}\end{array}$ & $\begin{array}{c}- \\
X \\
\text { S.E } \\
P \\
\end{array}$ & $\begin{array}{l}27.8 \\
0.59\end{array}$ & $\begin{array}{l}28.4 \\
1.08\end{array}$ & $\begin{array}{l}26.2 \\
1.45\end{array}$ & $\begin{array}{c}\text { Total } \\
\text { Lipids } \\
\text { g\% }\end{array}$ & $\begin{array}{c}- \\
X \\
\text { S.E } \\
P \\
\end{array}$ & $\begin{array}{c}452.2 \\
1.2\end{array}$ & $\begin{array}{c}402.6^{*} \\
2.77 \\
\leq 0.01\end{array}$ & $\begin{array}{c}402.6^{*} \\
2.3 \\
\leq 0.01\end{array}$ \\
\hline $\begin{array}{l}\mathrm{ALT} \\
\mathrm{U} / \mathrm{ml}\end{array}$ & $\begin{array}{c}- \\
X \\
\text { S.E } \\
P \\
\end{array}$ & $\begin{array}{c}24.8 \\
1.3\end{array}$ & $\begin{array}{l}23 \\
0.8\end{array}$ & $\begin{array}{c}23.5 \\
0.9\end{array}$ & $\begin{array}{c}\text { Choleste-rol } \\
\mathrm{mg} / \mathrm{dL}\end{array}$ & $\begin{array}{c}- \\
X \\
\text { S.E } \\
P \\
\end{array}$ & $\begin{array}{c}131.4 \\
2.44\end{array}$ & $\begin{array}{l}128.8 \\
2.17\end{array}$ & $\begin{array}{c}128 \\
5\end{array}$ \\
\hline $\begin{array}{l}\gamma \mathrm{GT} \\
\mathrm{U} / \mathrm{L}\end{array}$ & $\begin{array}{c}- \\
X \\
\text { S.E } \\
P\end{array}$ & $\begin{array}{c}12.68 \\
0.2\end{array}$ & $\begin{array}{c}14 \\
1.22\end{array}$ & $\begin{array}{c}12.72 \\
1.22\end{array}$ & $\begin{array}{c}\text { Tri- glyceride } \\
\text { mg/dL }\end{array}$ & $\begin{array}{c}- \\
X \\
\text { S.E } \\
P\end{array}$ & $\begin{array}{c}90 \\
3.16\end{array}$ & $\begin{array}{c}91 \\
3.14\end{array}$ & $\begin{array}{l}94 \\
1.6\end{array}$ \\
\hline $\begin{array}{l}\mathrm{LDH} \\
\mathrm{U} / \mathrm{L}\end{array}$ & $\begin{array}{c}- \\
X \\
\text { S.E } \\
P\end{array}$ & $\begin{array}{l}244 \\
4.56\end{array}$ & $\begin{array}{c}236.8 \\
3.32\end{array}$ & $\begin{array}{l}232 \\
3.34\end{array}$ & $\begin{array}{l}\text { Total } \\
\text { Protein } \\
\text { g\% }\end{array}$ & $\begin{array}{c}- \\
X \\
\text { S.E } \\
P \\
\end{array}$ & $\begin{array}{l}7.56 \\
0.38\end{array}$ & $\begin{array}{c}6.7 \\
0.22\end{array}$ & $\begin{array}{l}6.5 \\
0.2\end{array}$ \\
\hline $\begin{array}{l}\mathrm{CPK} \\
\mathrm{U} / \mathrm{ml}\end{array}$ & $\begin{array}{c}- \\
X \\
\text { S.E } \\
P\end{array}$ & $\begin{array}{l}1182 \\
3.62\end{array}$ & $\begin{array}{l}170 \\
3.16\end{array}$ & $\begin{array}{l}168 \\
2.28\end{array}$ & $\begin{array}{c}\text { Albumin } \\
\mathrm{g} \%\end{array}$ & $\begin{array}{c}- \\
X \\
\text { S.E } \\
P\end{array}$ & $\begin{array}{l}4.38 \\
0.31\end{array}$ & $\begin{array}{l}3.92 \\
0.22\end{array}$ & $\begin{array}{l}3.98 \\
0.16\end{array}$ \\
\hline $\begin{array}{c}\text { Alkaline } \\
\text { Phosph. } \\
\text { U/L }\end{array}$ & $\begin{array}{c}- \\
X \\
\text { S.E } \\
P\end{array}$ & $\begin{array}{l}3.2 .8 \\
1.8\end{array}$ & $\begin{array}{l}31.6 \\
1.5\end{array}$ & $\begin{array}{l}32.8 \\
1.03\end{array}$ & $\begin{array}{c}\text { Globulin } \\
\text { g\% }\end{array}$ & $\begin{array}{c}- \\
X \\
\text { S.E } \\
P\end{array}$ & $\begin{array}{c}2.7 \\
0.08\end{array}$ & $\begin{array}{l}2.58 \\
0.03\end{array}$ & $\begin{array}{l}2.72 \\
0.03\end{array}$ \\
\hline $\begin{array}{l}\text { Acid Phosph. } \\
\text { U/ml }\end{array}$ & $\begin{array}{c}- \\
X \\
\text { S.E } \\
P\end{array}$ & $\begin{array}{c}34.66 \\
.44\end{array}$ & $\begin{array}{c}35.2 \\
2\end{array}$ & $\begin{array}{l}32.6 \\
0.92\end{array}$ & $\begin{array}{c}\text { Urea } \\
\text { Nitrogen } \\
\text { mg\% }\end{array}$ & $\begin{array}{c}- \\
X \\
\text { S.E } \\
P \\
\end{array}$ & $\begin{array}{c}34.98 \\
0.4\end{array}$ & $\begin{array}{c}28.6^{*} \\
1.16 \\
\leq 0.01 \\
\end{array}$ & $\begin{array}{c}25.1^{*} \\
0.28 \\
\leq 0.01\end{array}$ \\
\hline
\end{tabular}


Anti - diabetic and anti-obesity effects........

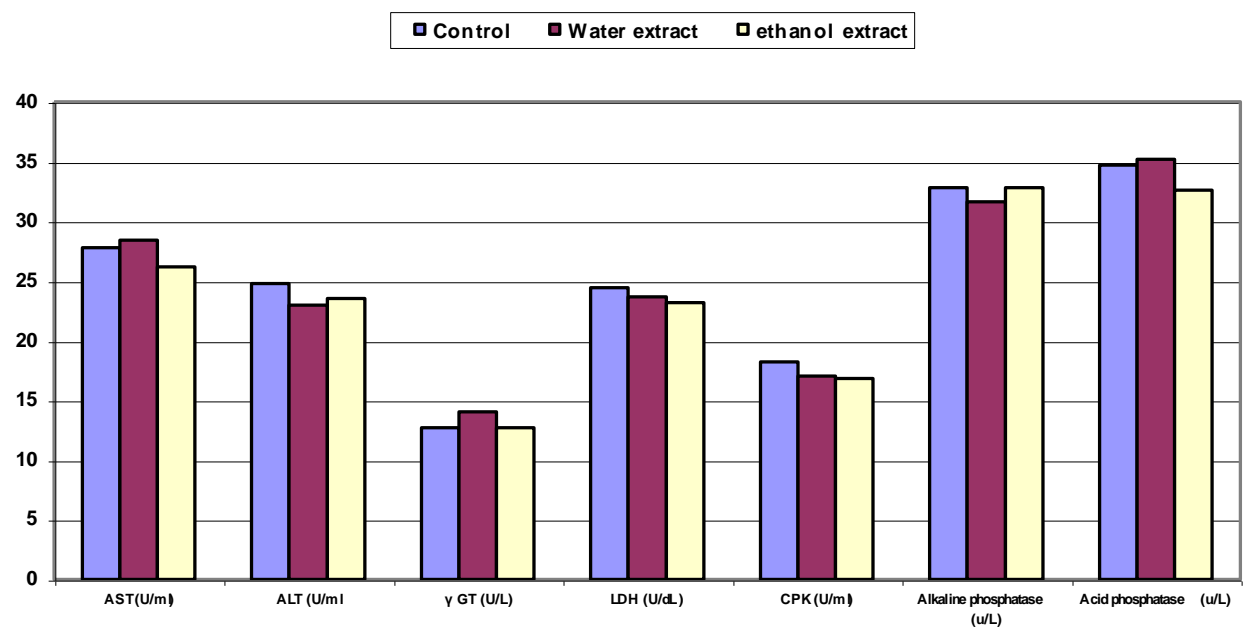

Figure (4): Liver and kidney function enzymes.

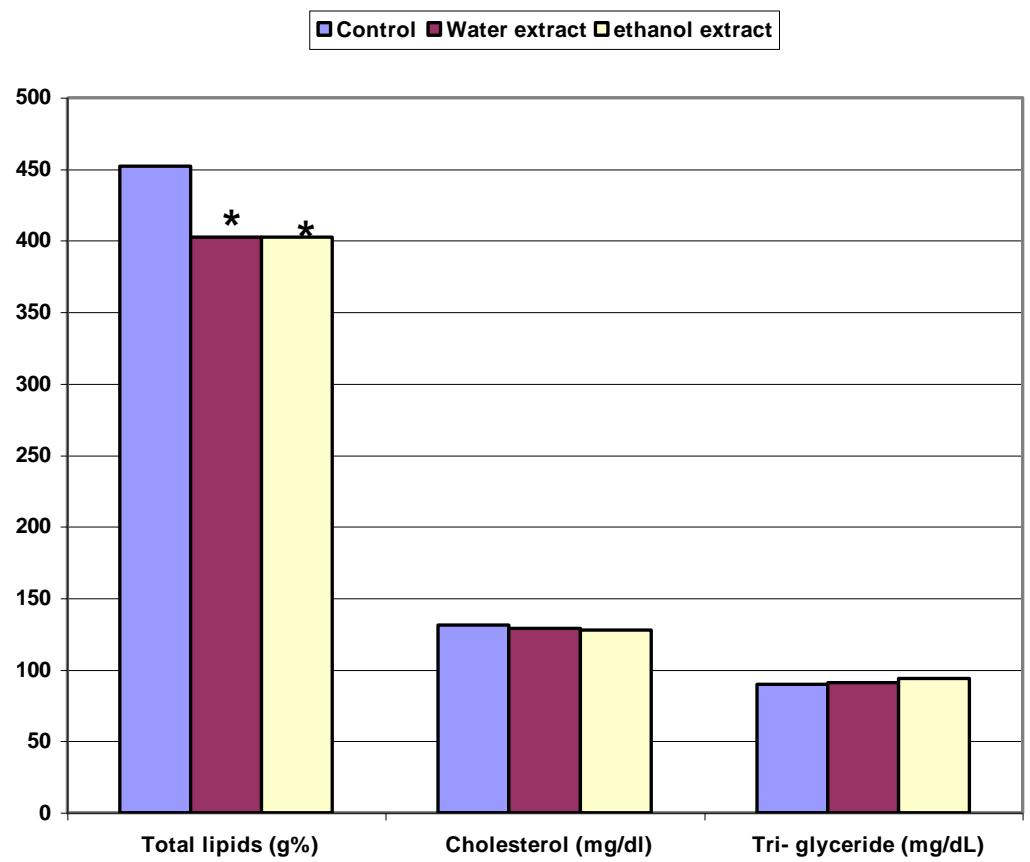

Figure (5): Lipid profile. Asterisks indicate a mean value significant $(\mathrm{p} \leq 0.05)$ from the mean of control. 


\section{$\square$ Control $\square$ Water extract $\square$ ethanol extract}

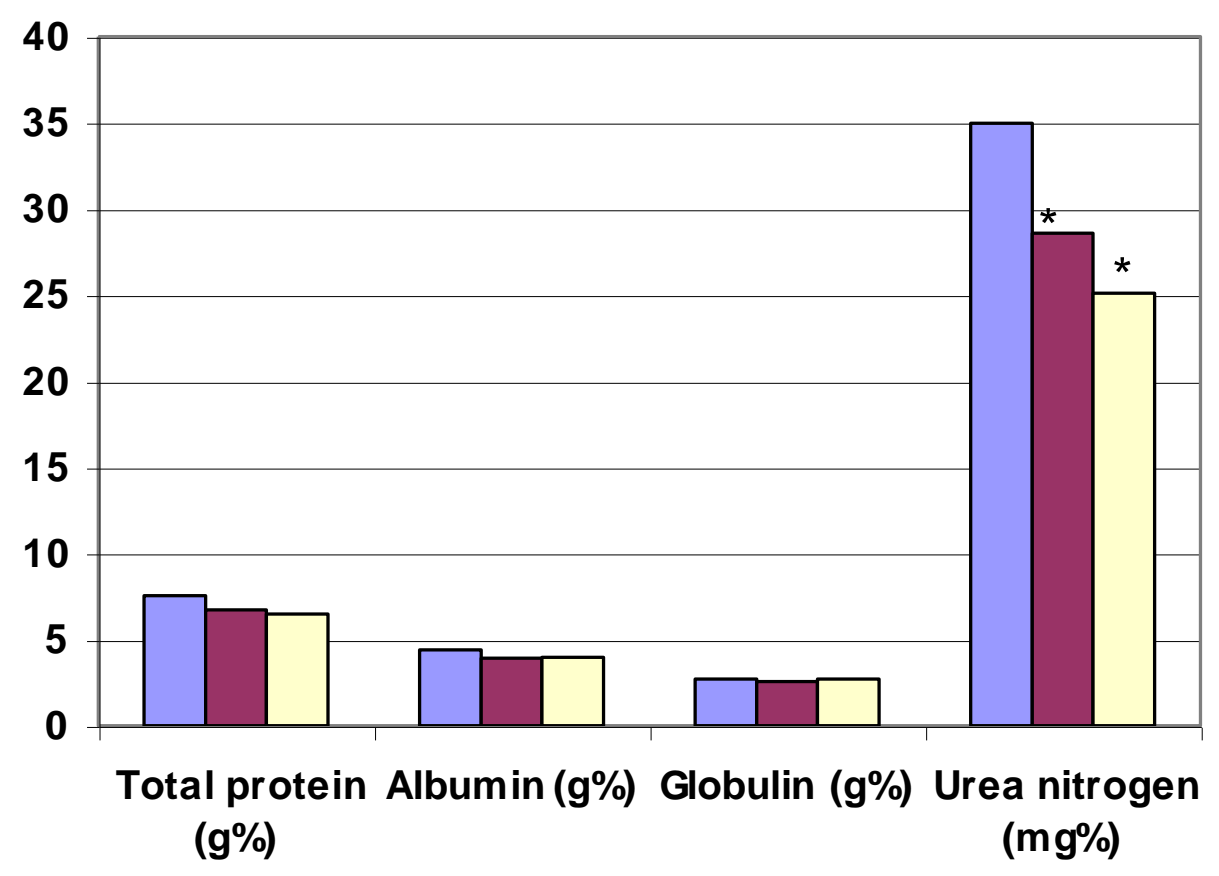

Figure (6): Protein and urea nitrogen. Asterisks indicate a mean value significant $(\mathrm{p} \leq$ 0.05) from the mean of control.

\section{Histological results:}

Plate (1) illustrates the histological features of control and treated rat liver. At low power, the liver cords are less regularly arranged in treated animals than control. The central vein is slightly congested. At high power, most of the control nuclei are vesicular; this is less noticed in sections from treated animals. More kupffer cells are noticed in sections of treated animals. The mean nuclear diameter of hepatocytes of treated animals is significantly smaller than control (Table 5, figure 7). Frequency distribution analysis of liver nuclear diameter (Figure 8) indicates three population of nuclei in control sections: a small size population representing Kupffer and endothelial cells, a population with larger size nuclei representing newly formed nuclei and/or less active hepatocyte nuclei, and a population of large nuclei representing the active vesicular nuclei. In sections from treated animals, the population of Kupffer and endothelial cells is very high, the population of cells with small nuclei is slightly higher than control, and the population of vesicular nuclei is much smaller than control. 
Anti - diabetic and anti-obesity effects........
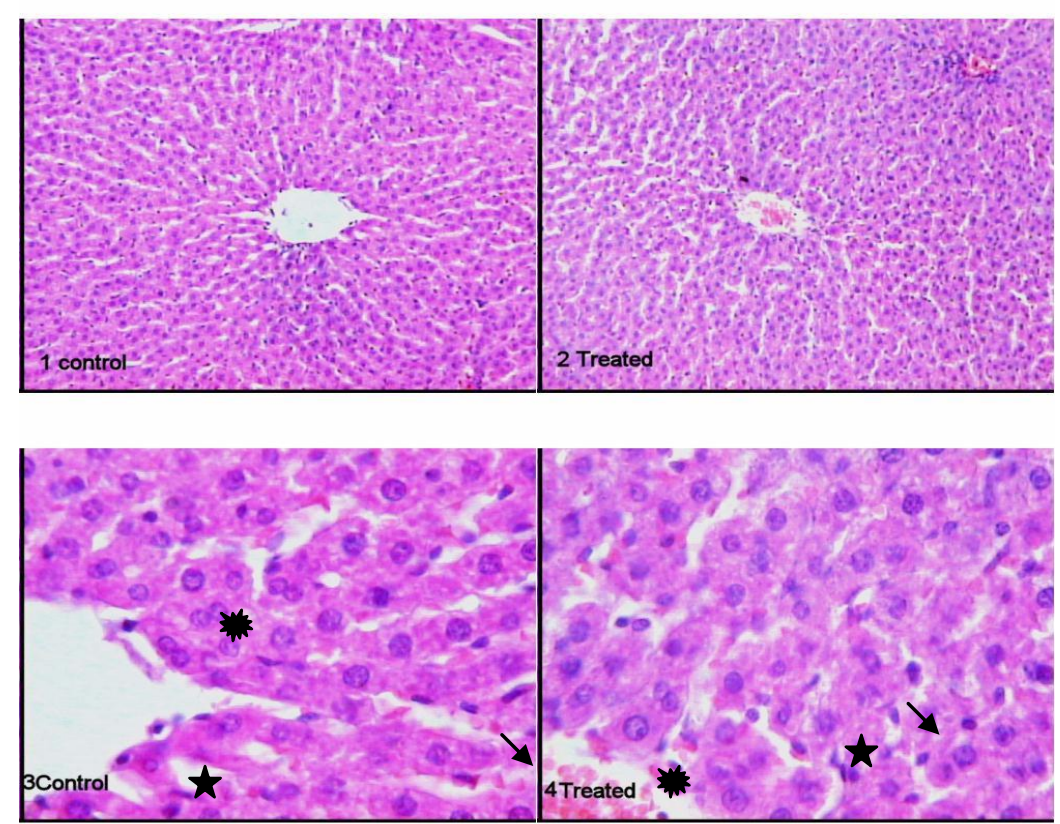

Plate (1): Section in liver of control and treated animals. $\downarrow$ ) endothelial nucleus ( ) vesicular hepatocyte nucleus ( $>$ ) Kupffer cell nucleus. (Hx,E.X400)

Table (5) Mean nuclear diameter of liver and kidney cells

\begin{tabular}{|l|l|l|l|}
\hline Organ & Group & Mean \pm Stdev. & t-test $(\mathrm{p} \leq)$ \\
\hline \multirow{2}{*}{ Liver } & Control & $5.84 \pm 4.04$ & \\
\cline { 2 - 4 } & Treated & $3.48 \pm 2.68$ & $3.2 \times 10^{-49}$ \\
\hline \hline \multirow{2}{*}{ Kidney } & Control & $5.24 \pm 2.8$ & \\
\cline { 2 - 4 } & Treated & $4.89 \pm 3.25$ & 0.11 \\
\hline
\end{tabular}

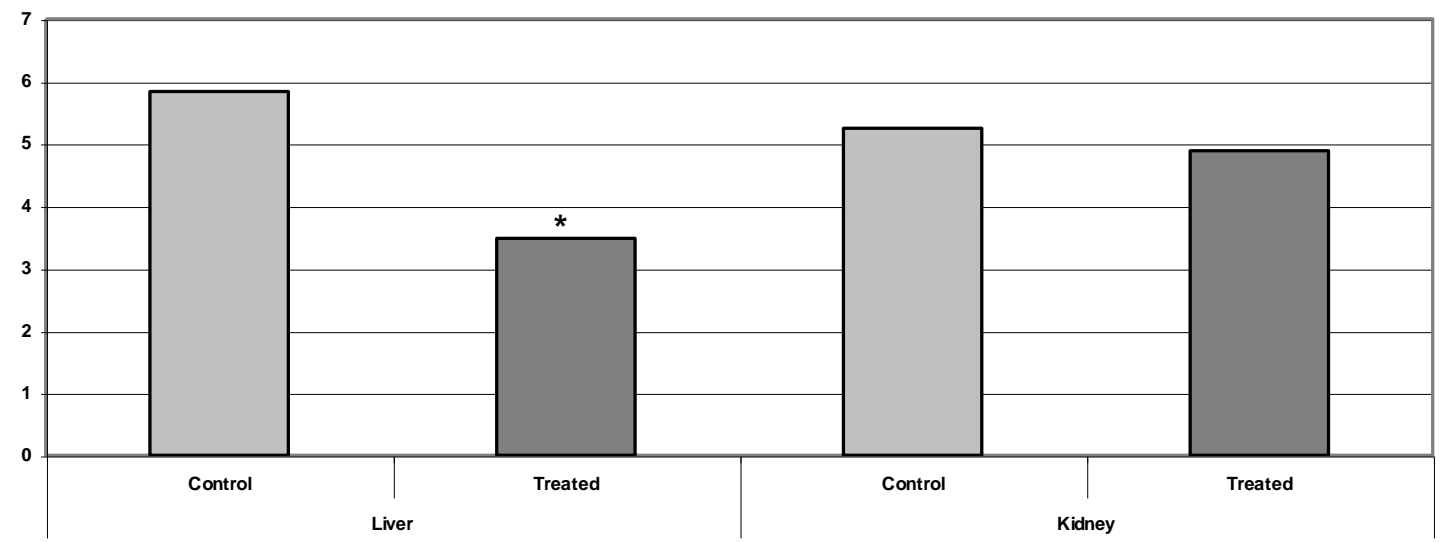

Figure (7): Mean nuclear diameter of kidney and liver cells. Asterisks indicate a mean value significant $(\mathrm{p} \leq 0.05)$ from the mean of control. 
Sections of kidneys from control and treated animals (Plate 2), show minor morphological differences. The mean nuclear diameter (Table 5, figure 7) has no statistically different values compared with control.

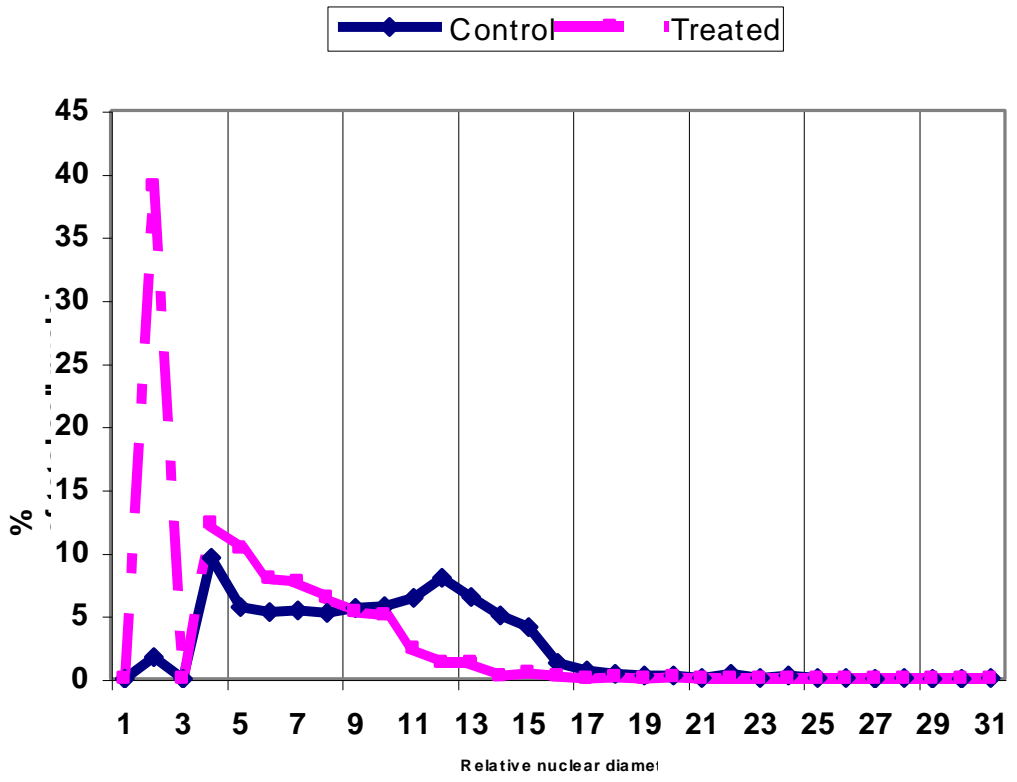

Figure (8): Frequency distribution of nuclear diameter of control and treated hepatocyte nucl
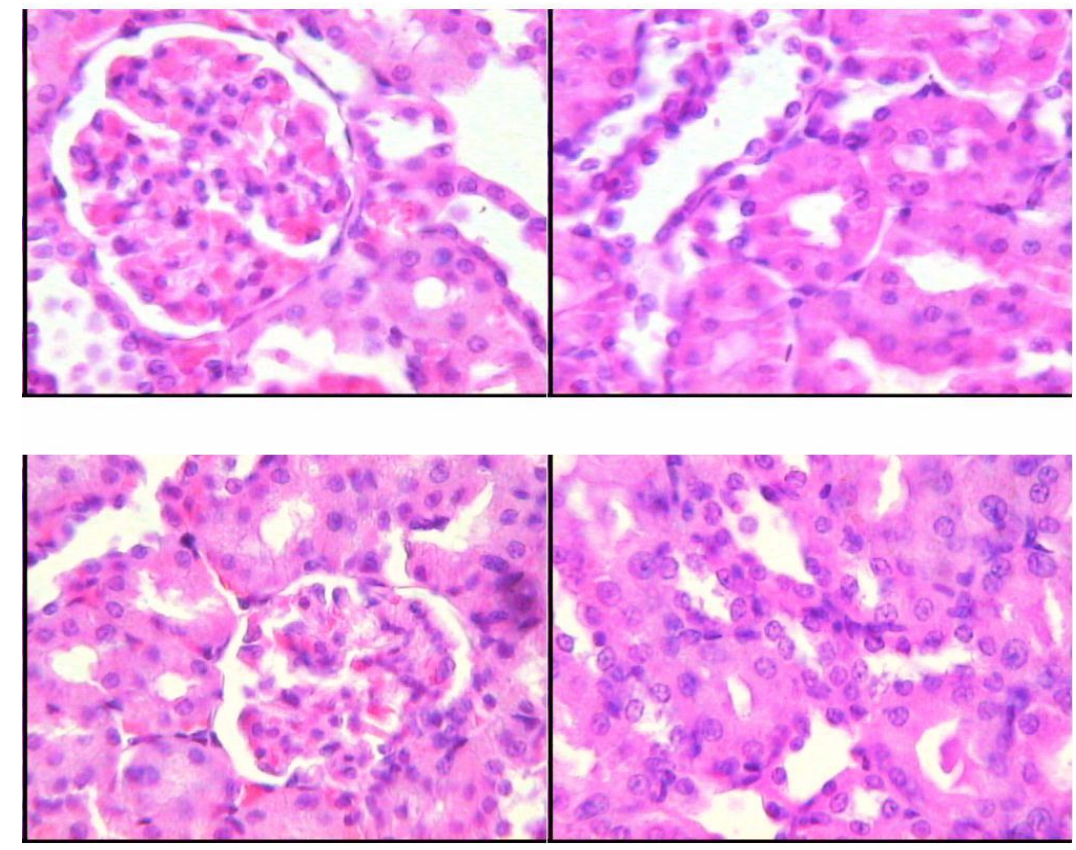

Plate (2): Section in Kidney of control (upper sections) ant treated (lower sections) animals. The difference in the diameter of the capsules is due to the level of sectioning. (Hx,E.X400) 


\section{Discussion}

There is a great need for evaluation, identification of active ingr edients, the mode of action and safety of the herbs used in folk medicine. Samwa (Cleome droserifolia) is one of the herbs used in Egyptian folk medicine by Sinai Bedouins as a remedy for diabetic patients. In the present study, evaluation of administration of water and ethanol extract of samwa was performed on senile diabetic rats. Such study is expected to be more informative than studies on experimentally induced diabetes( Mattar and Moustafa, 1994; Moustafa et al., 1995). The senile rats proved to be diabetic as revealed from the high basal blood glucose and glucose tolerance curve.

In the present study, drenching of either water or ethanolic extract to senile diabetic rats resulted in a significant drop in serum glucose level and increase in liver glycogen. This may be due to stimulation of the secretion of insulin by $\beta$ cells, inhibition of $\alpha$ cells of the pancreatic islets, or production of hyperglycemic factors, or by enhancing insulin activity. (Winkelman, 1989). This increase may be, also, as observed here, due to increased activity of glycogen synth etase induced by the plant extract as reported, also, after administration of garlic oil (Rawi et al., 1996) and Gymnea sylvestra extracts (Shanmuga sundaram et al.,1990). The increased enzyme activity may be due to direct effect of the extracts, or indirect through induced insulin hormone release which activates glycogen synthetase ( Gold. 1970). The level of insulin was higher in animals drenched either extract and glucagons was lower than control. However, the change in the level of both hormones was not statistically significant.
The total serum lipids in treated animals was statistically lower than control. A similar decrease in serum total lipids was also reported in rats treated with fruit extract of B. egyptiaca in alloxan induced diabetes (Helal, 2000,Mattar and Helal,2001). The level of serum triglycerides and cholesterol, however, was not significantly different from control. The decrease in total lipid, therefore, may be due to a comparable decrease in free fatty acids (Harper et al, 1993). Such a decrease is expected in the case of accumulation of fat in adipocytes, both by synthesis and decreased liberation of fatty acids. Accumulation of fat in adipocytes is possibly the reason behind the high level of the fat cell- produced hormone, leptin (Mattar and Helal, 2001; Bennett et al.,1997) in the serum of treated rats. Increased leptin level may be also due to direct action of some extract components on the adipocytes (Mattar and Helal,2001).

The high level of serum leptin is expected to induce loss of apetite through repression of the hypothalamic neuropeptide Y (NPY) production (Baranowska et al., 1999). The loss of appetite is expected to result in symptoms of undernourishment (Maffei et al, 1995) such as decreased intake of amino acids and iron. Decreased amino acid uptake may explain the observed low level of serum urea in treated animals due to depression of deamin ation and ornithine cycle in the liver (Harper et al, 1993).

The observed high testosterone level in treated animals is expected as a result of high leptinemia and low NPY production(Himms-Haagen, 1999). NPY is a regulator of gonadotropin releasing hormone production (Nagatoni et al. 1998) which induces the production of pituitary gonadotropins (Keisler et al., 1999). 
The present study revealed that the oral administration of samwa extract to senile diabetic rats caused alterations in some haematological and biochemical parameters. Our results showed signif icant decrease in RBCs, Hb and Hct and these results may be attributed to the synchronous significant decrease in serum iron of treated rats. Iron defici ency, and hence, signs of anemia obser ved in the results, may be attributed to malabsorption mediated by leptin action (Maffei et al, 1995).

Test for the toxicity of the extracts using the biochemical analysis of liver, kidney and heart functions indicated that they were safe. The parameter used to test these functions in treated animals did not differ significantly from those of control animals.

Histological evaluation of kidney sections of extract drenched animals revealed almost no morphological difference from control. The variation in mean nuclear diameter of kidney cells of treated animals was, also, not signi ficantly different from control. Although the results of biochemical and histological results may indicate that drenching SAMWA extract is safe on rat kidney, more investigations are needed to ensure these results.

The histological investigation of liver section, however, showed distu rbed arrangement of liver cords and congestion of central vein in the liver of treated animals as compared to control. The mean nuclear volume was signify cantly smaller in treated animals than control. Analysis of frequency distrib ution of nuclear diameter indicated a large population of cells with the diameter of Kupffer and endothelial cells. The population of nuclei in the range of diameter of less active nuclei was higher than control, while the population of nuclei representing active vesicular nuclei was much lower than control.

The increased Kupffer cell popul ation may indicate active role of these cells in phagocytosis of RBCs which is normally met with in cases of iron deficiency (Nicolas et al., 2002) as observed in this study. The application of the plant extract may, therefore, be harmful and repress the vital activities of the liver.

In conclusion, although the extract of SAMWA results in a decrease in blood glucose level and an increase in leptin which may act as anridiabetic and anti-obesity, more careful investigation is needed to test its safety. The invest igation on this plant should also conce ntrate on the isolation of different gradients rather than whole extract in order to identify the active non-harmful ingredients which can play the role of anti-diabetic anti-obesity effect without harmful side effects.

\section{References}

1. Baird, J.D. (1984): Endocrine and metabolic diseases. In : Davidson's Principals and Practice of Medicine, $14^{\text {th }}$. Ed., Macleod, J. editor, P458. English Language Book Society/ Churchill Livingstone Edinburgh.

2. Baranowska, B.; Radzikowska, M.; Wasilewska - Dziubinska, E.; Kaplinski, A.; Roguski, K. and Plonowski, I.(1999): Neuropeptide Y, Leptin, galanin and insulin in women with poly cystic ovary syndrome, Gynecol endocyinol; 13 (5): 344-351.

3. Belifield, A. and Goldberg, S. (1971): Revised assay for serum phenylpho sphatase activity using 4-aminoantiprine. Enzym, 12:561.

4. Bennett, F.I.; McFarlane-Anderson, N.; Wilks, R.; Luke, A.; Cooper, R.S. and Forrester, T.E.(1997): Leptin co ncentration in women is influenced by regional distribution of adipose tissue. Am. J. Clin. Nutr, 66:1340-1344. 
5.Cara, N.V.; Robert, W.L. and Joseph, H.R. (1956): The determination of glycogen in liver and muscle by use of anthron reagent. J. Biol. Chem., 220:583-593.

6. Crisan, A. and Hodis, A. (1972): Studies on the fungistatic and fungicidal activity of some medicinal plant extract and essential oils. Clug. Rumania 46: 171-179.

7.Doumas, B.T. (1975): Standards for total serum protein assays. A collaborative study. Clin. Chem., 21(8): 1159-1161.

8.Drury, R.A.B. and Wallington, E.A. (1980): Carleton's Histological Technique, $5^{\text {th }}$ ed. Oxoford, New York, Toronto.

9.Efendic, S.; Cerasi, E. and Luff, R. (1971): Role of glucose in arginineinduced insulin release in man. Metab., 20:568-579.

10. El-Seifi, S.; Abdel-Moneum, A. and Badeir, N. (1993): The effect of Ambrosia maritima and cleome droserifolia on serum insulin and glucose concentration in diabetic rats. J. Egypt Ger. Soc. Zool., 2(a):305-238.

11. Farrage, R.S.; Salem, H.; Badei, A.Z. and Hassanein, D.E. (1986): Biochemical studies on the essential oils of some medicinal plants. Fette. Seifen Austrichmittel, 88(2): 69-72.

12. Fossati, P. and Medici, R. (1987): Abstract book : International symposi um on cholesterol control and radiov ascular diseases : prevention and ther apy. Milan, Italy.

13. Gepts, W. (1972): Pathology of islet tissue in human diabetes. In Steiner D.F. \& Freinkel, N. (Eds.) Handbook of physiology section Z, Endocrinology, 1:289-303.

14. Gerich, J.E. ;Charles, M.A. And Grodsky,G.M.(1974): Characterization of the effect of arginine and glucose on glucagon and insulin release from the perfused rat pancreas. J.Clin.Invest., 54: 833-841.

15. Gold, A.H. (1970): The effect of diabetes and insulin on liver glycogen synthetase activation.J. Biol. Chem. 245: 903-905.
16. Grieve, M. (1959): A modern Herbal vol(1). Hafner publishing co., New York, pp. 70-76.

17. Grunfeild, C.; Jones, S. and Shigenda, A. (1995): Auto antibodies against insulin receptor. Dissociation of acute effect of antibodies from desensi tization seen with prolonged exposure. Diabetes, 34: 305

18. Harper, H.A.; Rodwell, V.W. and Mayes, P.A. (1993): A review of phy siological chemistry. Lange Medical Publications, Los Altos, California.

19. Heding,K.G.(1971):Radioimmunologi cal determination of pancreatic and gut glucagon in plasma. Diabetologia, 7:1017.

20. Helal, E.G.E. (2000): Effect of Balanitus aegyptiaca fruits on some physiological parameters in alloxan diabetic rats. Al-Azhar Bull Sci. 11(1): $325-347$.

21. Himms - Haagen, J. (1999): Physicological roles of the leptin endocrine system: differences between mice and humans Crit. Rev. Clin. Lab. Sci. 36(6): 575-655.

22. Kaur, S. and Shinna, G.K. (1982): Antibacterial activity of volatile oils and their important constituents from some indigenous plants. Indian J. of Physical and Natural Science, 2: 6 -47.

23. Keisler, D.H.; Daniel, J.A. and Morrison, C.D. (1999): The role of leptin in nutritional status and reprodu ctive function. J. reprod. Fertil. Suppl; 54:425-435.

24. King, E.J. and Armstrong, A.R. (1934): A convenient method for determining serum and bile phosph atase activity. Canada. Med. Assoc. J., 31:376-381.

25. Knight, J.A.; Anderson, S. and Rawie, J.M. (1972): Chemical basis of the sulfophosphovanillin reaction for estimation of total serum lipids. Clin. Chem., 18(3): 199-202.

26. Levin, S.R.; Grodsky, G.M.; Hagura, R.; Smith, D.F. and Forsham, P.H. (1972): Relationship between arginine and glucose in the induction of insulin secretion from the isolated perfused rat pancreas. Endocrinology, 90: 624-631. 
27. Maffei, M.J.; Haluns, E.; Revassin, R.E.; Pratley, G.H.; Les, Y. ; Zhang, H.; Fei, S.; Kirn, R.; Lallone, S.; Ranganathan, P.A.; Kern and Friedman, J.M. (1995): Leptin level in human and rodents measurement of plasma leptin and obRNA in obese and weight reduced subjects. Nut. Med., 1:1155-1161.

28. Maruyama, Y. (1987): Sex-steroidbinding plasma protein (SBP), Testerterone, Oestradiol and DHEA in Prepuberty and Puberty, Acta Endocrinologica, 114: 60-67.

29. Mattar, F.E. and Helal, E.G.E. (2001): Effect of Balanitus egyptiaca seed extract on factors affecting serum glucose level in hyperglycemic senile albino rat. Al-Azhar Bull.Sc. 12(2): 231-245.

30. Mattar, F.E. and Moustafa, S.A. (1994): Effect of aging and the fat soluble antioxideant BMT on glucose tolerance in male rats. Egypt. J. Med. Sci.; 15(2):353-358.

31. Meister, A.; Tate, S.S. and Griffith, O.W. (1981): $\square$-glutamyltra-nspep tidase. Method Enzymol., 77:237-253.

32. Moustafa, S.A.; Webster, J.E. and Mattar, F.E. (1995): Effects of aging and antioxidants on glucose transport in rat adipocytes Gerontology, 41:301307.

33. Nagatoni, S.; Guthikonda, P.; Thompson, R.C.; Tsukamura, H.; Maeda, K.I., and Foster, D.L. (1998): Evidence for $\mathrm{GnRH}$ regulation by leptin: Leptin administration prevents reduced pulsatile LH secretion during fasting. Neuroendocrinology 67(6): 370-376.

34. Nicolas, G.; Chauvet, C.; Viatte, L.; Danan, J.L.; Bigard, X.; Devaux, I.; Beaumont, C.; Kahn, A.; Vaulont, S. (2002): The gene encoding the iron regulatory peptide hepcidin is regulated by anemia, hypoxia, and inflammation. J Clin Invest. 2002 Oct;110(7):1037-44.

35. O'Brien, B.A.; Harmon, B.V.; Cameron, D.P. and Allan, D.J. (1996): Beta cell apoptosis is respon sible for the development of IDDM in the multiple dose streptozo -tocin model. J.Pathol., 178(2): 176-181.

36. Raabo, E. (1963): Determination of serum lactic dehydrogenase by the tetrazolium salt method. Scand. J. Clin. And Lab - Invest., 15:233-235.

37. Rahier, J.; Geobbels, R.M. and Henguin, J.C. (1983): Cellular composition of the human diabetic pancreas. Diabetologia, 24:366-370.

38. Rawi, S.M.; Abdel Moneim, A. and Ahmed, O.M. (1996): Studies on the effect of garlic oil and glibenclamic on alloxan diabetic rats. 1-Hypoglycemic and histopathological effects. J. Union Arab Biol., 6(A): 121-142.

39. Reaven, G.M.(1984): Insulin secretion and insulin action in non-insulin depe ndent diabetes mellitus. Which defect is primary? Diabetes Care, 7: 17-23.

40. Reitman, S. and Frankel, S. (1975): A colourimetric method for the deter mination of serum glutaifdc oxaloacetic and glutamic pyrovic transaminases. Am. J. Clin. Path., 28:56 - 60.

41. Roberto, C. (1984): Macdonald encyc lopedia of Medicinal Plants. Macdonald and Co. (Publishers) Ltd., London and Sydney. pp. 622-635.

42. Rodak, F.P. (1995): Routin laboratory evaluation of blood cells and bone marrow. In : Diagnostic hematology, pp. 125-129, W.B. Saunders Comp. Phild. London, Toronto, Montreal, Sydney, Tokyo.

43. Rojkin, M.L.; Olguin, D.E.; Mariani, M.C.; Drappo, G.A.Y. and Sosa, C.P. (1974): Proteinastotales del sureo: causas mas frecuentes de error en la roaccion del Biuret Nuevo reactivo cuproal calino estable. Broq. Del Atantico, 11: 1163-1193.

44. Rosalki, S.B. (1967): Recommended method for the determination of crea tine kinase in blood. J. Lab. Clin. Med. 69:696 -699.

45. Schermer, S. (1967): The blood morp hology of laboratory animals. Longmans, Green and Co. Ltd., Los Altos, California. p. 350.

46. Shanmugansundaram,E.R.;Gopinath K.L.; Radha, S.K. and Rajendram, V.M. (1990): Possible regeneration of 
the islets of langerhans in streptoz otocin diabetic rats given Gymnema sylvestra leaf extracts. J. Ethenoph armarol, 39(3): 265-279.

47. Siest,G. and Schielf, M.J.(1981) : Interpretation des examens de labor atoire, Karger ed. pp.206-223.

48. Sokal, R.R. and Rahif, F.J. (1981): The Principles and practice of statistics in biological Research. $2^{\text {nd }} . \quad$ Ed., Freeman, WH. Co. San Fransisko.

49. Van-Kampen, E.J., and Zulstra, W.G.(1961): Standardization of hemo globinometry: The hemoglobin cyanide method. Clin. Chem. Acta, 7:538 540.
50. Webester, D.(1977): Albumin standards and measurement of serum albumin with bromocresol green. Clin. Chem., 23: 663-666.

51. Winkelman, M.(1989): Ethnobotanical treatment of diabetes in Baja California. Norte.Med. Anthrop.,11: 253 - 268.

52. Yoon, J.M. (1990): The role of viruses and environmental factors in the induction of diabetes. Curr. Top. Microbiol. Immunol., 164: 95-123.

53. Zhongmin, M.(1996):Radio-immuno assay of leptin in human plasma . Clin Chemistry, 42: 942 - 946. 


\section{التأثير المضاد لمرض البول السكري والسمنة لمستخلص نبات كليومي دروسبيريفوليا (السامواه)}

$$
\begin{aligned}
& \text { * إيمان هلال ، ** حفيظة شرف ، *** فتحي مطر }
\end{aligned}
$$

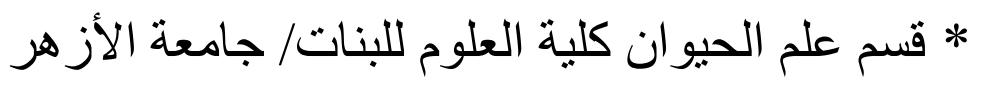

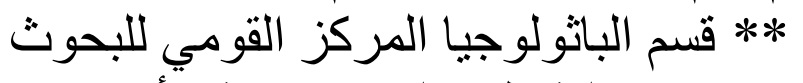

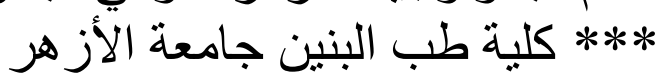

في هذا البحث تم دراسة تأثير المستخلص المائي لنبات كليومي دروسيريفوليا

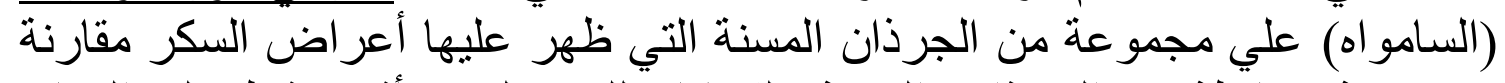

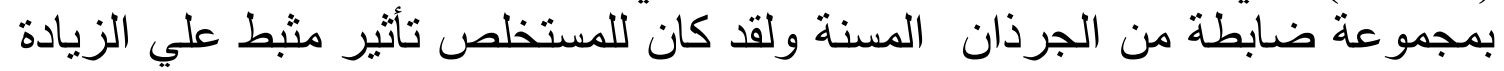

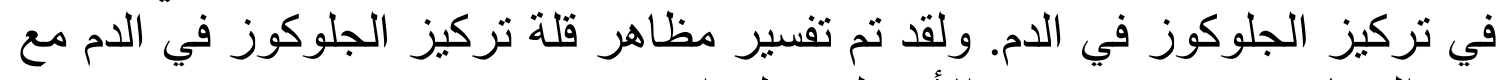

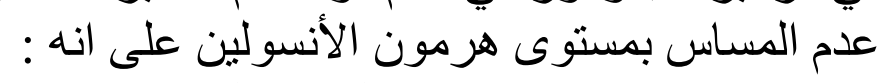

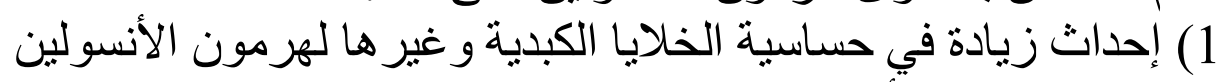

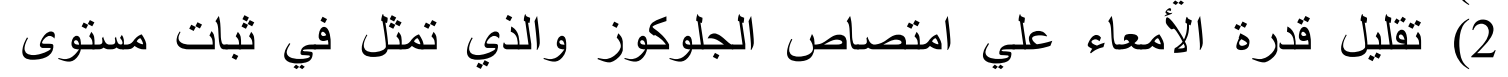

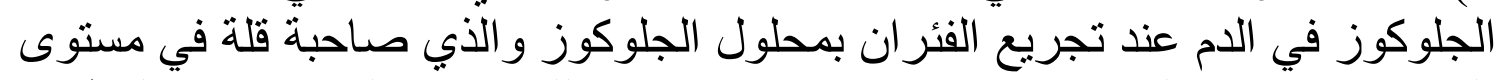

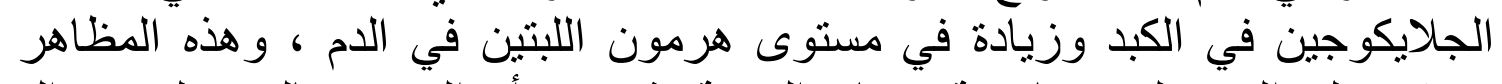

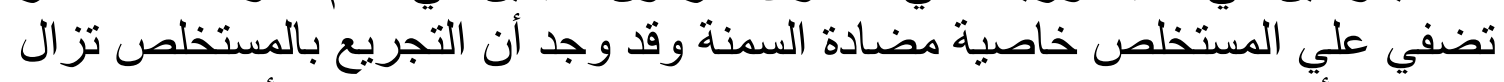

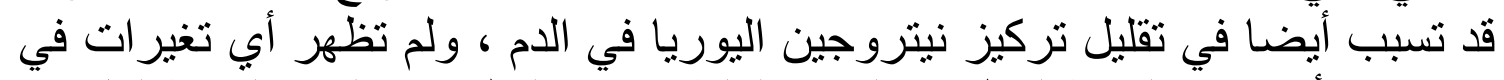

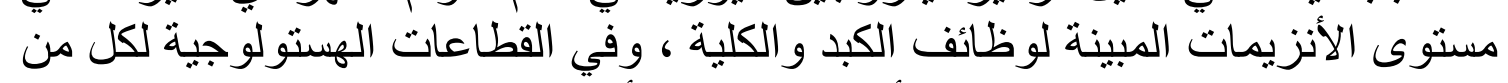

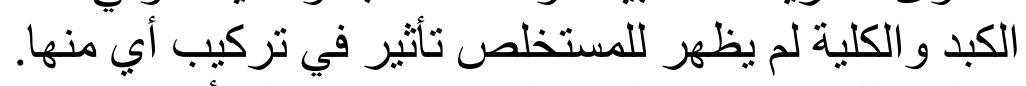

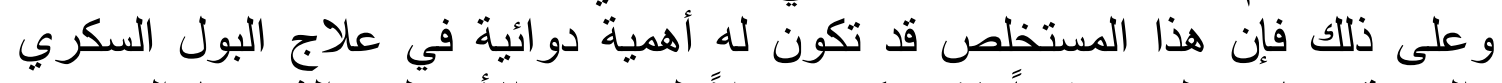

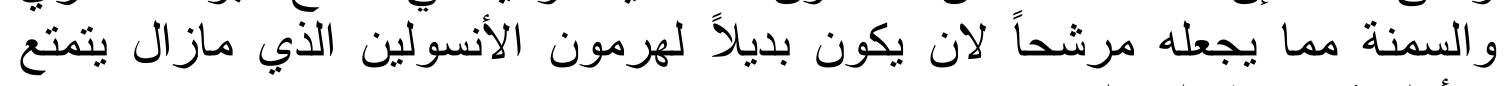
بالأولوية في هذا المجال. 